\title{
MIA COUTO, UM AUTOR EM CONSTANTE DESLOCAMENTO
}

\section{MIA COUTO, AN AUTHOR IN CONSTANT \\ DISPLACEMENT}

\author{
Raquel Aparecida Cesar da Silva \\ Márcia Helena Saldanha Barbosa
}

\section{RESUMO}

A literatura produzida na África ocupa uma posição ainda incerta no panorama cultural do Ocidente, tanto pela condição incipiente de sua produção quanto pelo pensamento, profundamente arraigado, de que haveria uma essencialidade africana a ser preservada contra toda e qualquer forma de intercâmbio, inclusive o intercâmbio de ideias. Porém, a verdade é que tal essencialidade, se de fato existiu, há muito que se tornou uma ilusão projetada sobre o continente de fora para dentro. Partindo desse princípio, o trabalho aqui apresentado procura analisar de que maneira a literatura e o pensamento do autor moçambicano Mia Couto, ao se afastarem da suposta essencialidade africana, aproximam-se do que podemos considerar uma postura pós-modernista. Para tanto, recorremos a obras romanescas e ensaísticas do autor, assim como às ideias de Linda Hutcheon (1991), Homi Bhabha (2014) e Stuart Hall (2006) sobre identidade cultural e artística no pós-modernismo.

PALAVRAS-CHAVE: Mia Couto; Hibridismo; Cultura.

\section{ABSTRACT}

The literature produced in Africa occupies an uncertain position in the Western cultural panorama, both for the incipient condition of its production and the thought, deeply rooted, that there would be an African essentiality to be preserved against all forms of exchange, including the exchange of ideas. But the truth is that such essentiality, if indeed existed, has long become a illusion, projected on the continent from the outside. Ba- 
sed on this principle, the work presented here analyzes how the literature and ideas of the Mozambican author Mia Couto, by withdrawing from the supposed African essentiality, get closer to what one may consider a postmodernist position. For that, we turn to novels and assays written by the author, as well as the ideas of Linda Hutcheon (1991), Homi Bhabha (2014) and Stuart Hall (2006) on cultural and artistic identity in postmodernism.

KEYWORDS: Mia Couto; Hybridism; Culture.

A literatura produzida na África ocupa uma posição ainda incerta no panorama cultural do Ocidente, tanto pela condição incipiente de sua produção quanto pelo pensamento, profundamente arraigado, de que haveria uma essencialidade africana a ser preservada contra toda e qualquer forma de intercâmbio, inclusive o intercâmbio de ideias. Porém, a verdade é que tal essencialidade, se de fato existiu, há muito que se tornou uma ilusão projetada sobre o continente de fora para dentro. Desde o momento em que as nações do Ocidente, movidas pelos mais diversos interesses, passaram a se debruçar sobre as obscuras e misteriosas culturas orientais, e em que os países africanos começaram a utilizar a língua dos colonizadores europeus para pensar e escrever sobre a sua própria condição histórica, a hipotética pureza cultural deixou de existir, em ambos os lados.

Segundo o pesquisador indiano Homi Bhabha (2014), o tempo que vivemos hoje é um tempo deslocado de seu centro, um entrelugar, que não pode ser analisado em termos de fixidez de territórios e ideologias. Bhabha, quando trata daquilo que entende ser a imagem do Oriente em representações artísticas e manifestações culturais, ressalta a presença de um olho que procura fixar a imagem do outro, para que um indivíduo, um povo ou uma cultura possa perceber os pontos exatos em relação aos quais dele se diferencia. Esse olho representa a necessidade de entendimento e percepção de um signo estrangeiro, a um só tempo estranho e fascinante, ainda que a motivação original, ou principal, de tal necessidade seja menos o reconhecimento e a compreensão de uma cultura do que a pura e simples dominação de um povo. De todo modo, reconhecidos ou não, bem aceitos ou não, a mistura e o hibridismo parecem constituir a base sobre a qual se apoia a criação artística de nossa época.

No prefácio ao estudo em que aborda a produção estética em tempos de pós-modernismo, Linda Hutcheon (1991) afirma que "paradoxal" e "contraditório" são expressões recorrentes e preponderantes quando se procura compreender um período tão intensamente fugidio como o que se vive hoje. Além disso, a ensaísta oferece uma pequena pista sobre a postura que, via de regra, assume-se em relação a essa produção: "Em geral, os paradoxos podem causar prazer ou problemas. Dependendo da constitui- 
ção de nosso temperamento, seremos seduzidos por sua estimulante provocação ou perturbados por sua frustrante ausência de resolução" (1991, p. 12). Seduzidos ou perturbados, vivemos o paradoxo do nosso tempo, e é a partir dele que procuramos compreender a arte e a vida.

A busca pela definição mais precisa de uma arte pós-modernista levanta questões delicadas como a presença ou não do autor no objeto estético por ele criado e as relações que esse mesmo objeto é capaz de estabelecer com a "realidade" pregressa ou presente do meio no qual foi concebido. O pós-modernismo, na concepção de Linda Hutcheon, é, sobretudo, um conceito que se desloca, que se movimenta livremente em meio a obras, ideologias e disciplinas diferentes, alterando a todo o momento as perspectivas e as bases que lhe servem de suporte teórico e dificultando percepções e abordagens. É Homi Bhabha (2014, p. 19) quem aponta, no início de $O$ local da cultura, a maneira como encontramos no prefixo "pós" um ponto de fuga das questões de nosso próprio tempo:

É o tropo dos nossos tempos colocar a questão da cultura na esfera do além. Na virada do século, preocupa-nos menos a aniquilação - a morte do autor - ou a epifania - o nascimento do "sujeito". Nossa existência hoje é marcada por uma tenebrosa sensação de sobrevivência, de viver nas fronteiras do "presente", para as quais não parece haver nome próprio além do atual e controverso deslizamento do prefixo "pós": pós-modernismo, pós-colonialismo, pós-feminismo...

Bhabha dá continuidade a seu pensamento afirmando que esse "além" para o qual as pessoas se voltam tão insistentemente em busca de respostas para as perguntas que as afligem não pode ser tomado como expectativa em relação ao futuro, ou tampouco como um abandono absoluto do passado, justamente porque significa alteração, mudança, transição.

Stuart Hall, no livro intitulado A identidade cultural na pós-modernidade, investiga as questões relativas às identidades das nações que emergiram no século XXI recém-saídas de processos de descolonização, de acentuadas modificações nas características pessoais (no tocante a questões de gênero, de sexualidade e de etnia) e da relativização de identidades coletivas referentes a países e populações. Ele inicia seu estudo levantando hipóteses acerca da existência ou não de uma crise de identidade em escala global e do significado dessa possível crise em termos de mudanças no processo de interação entre continentes, países e pessoas. Segundo Hall (2006, p. 09), o sujeito, antes facilmente identificável com uma cultura específica e com uma igualmente específica maneira de se comportar em sociedade, já não encontra para si uma identificação adequada, que lhe complete como indivíduo:

Estas transformações estão também mudando nossas identidades pessoais, abalando a ideia que temos de nós próprios como sujeitos integrados. Esta perda de um "sentido de si" estável é chamada, algumas vezes, de deslocamento ou descentração do sujeito. Esse duplo deslocamento - descen- 
tração dos indivíduos tanto de seu lugar no mundo social e cultural quanto de si mesmos - constitui uma "crise de identidade" para o indivíduo.

$\mathrm{Na}$ passagem citada, Hall afirma que, de fato, existe uma crise gerada pelo período vivido atualmente, e que essa crise desenvolve-se no indivíduo como um crescente sentimento de inadequação e não pertencimento relacionados a diferentes níveis de sua vida. O pesquisador considera o hibridismo e a mestiçagem sociocultural o paradigma universal que aponta para o futuro sem ignorar tradições do passado, ressaltando que países emergentes de uma recente situação de opressão ideológica e de imposição linguística possuem a vantagem - conquanto vaga - de estarem situados um passo à frente das demais nações no que diz respeito ao processo de abertura de fronteiras sociais, políticas e, especialmente, culturais. Talvez esse seja o caso da África e, sobretudo, da arte produzida nesse continente, que, embora fortemente ancorada na história - ou seja, no passado -, é repleta de futuro, construindo e reconstruindo sistematicamente a sua própria identidade por meio do hibridismo resultante do embate entre culturas profundamente diferentes entre si.

Da mesma forma que Hall esclarece, já no início de seu livro, que esse estudo foi "escrito a partir de uma posição basicamente simpática à afirmação de que as identidades modernas estão sendo 'descentradas', isto é, deslocadas ou fragmentadas" (2006, p. 08), Linda Hutcheon dedica um capítulo inteiro da Poética do pós-modernismo ao conceito de ex-cêntrico, por meio do qual procura ressaltar a importância de elementos que se encontram fora do centro, ocupando posições periféricas e habitando as margens da história central. Mais do que a autorreferenciação, a inversão - com frequência paródica - de modelos, costumes e estilos, ou mesmo a expansão de fronteiras que caracterizam, segundo ela, o pós-modernismo, pode-se afirmar que é a descentralização - ou descentração, como quer Hall - da perspectiva crítica e ideológica acerca de nações, povos e obras artísticas que constitui, verdadeiramente, aquilo que Bhabha chamou de "o tropo de nosso tempo".

É nesse panorama que emerge a figura do jornalista, biólogo e escritor Mia Couto, nascido na cidade de Beira, em Moçambique, em 1955, apenas 20 anos antes da assinatura da declaração de independência desse país. Filho de um jornalista e poeta português e de uma mulher que carregava em si a poesia ${ }^{2}$, Antônio Emílio Leite Couto cresceu em um ambiente no qual a escrita e as histórias faziam parte da vida cotidiana. Em 1972, ingressou na faculdade de medicina da Universidade de Eduardo Mondlane, situada na capital do país, Maputo, mas jamais concluiu o curso, pois abandonou-o dois anos depois em favor de uma atividade híbrida de jornalista e militante político, à qual iria se dedicar até meados dos anos 80 , quando então regressaria à universidade para formar-se em biologia. 
Essa primeira bifurcação de caminhos - uma vivência literária de berço e uma opção profissional pelas ciências biológicas - seria apenas uma entre tantas contradições, reais ou aparentes, que viriam a marcar a vida desse homem branco, de ascendência europeia, que nasceu num país africano e que teve acesso a direitos então sonegados à imensa maioria do povo moçambicano. Mia Couto foi membro da chamada Frente de Libertação de Moçambique, a FRELIMO - organização fundada em 1962, que pretendia implantar no país um modelo econômico e social baseado no marxismo -, até o momento em que o objetivo da guerrilha por ela empreendida foi alcançado e Portugal se retirou oficialmente do país. Ele acabou por se afastar da FRELIMO somente quando, uma vez transformada em partido político, a organização tomou o poder e permitiu que Moçambique mergulhasse numa brutal guerra civil que perduraria até meados de 1992.

A história de Mia Couto é absolutamente indissociável da história recente de seu país de nascimento. Não existe maneira de aludir a seus textos literários sem, de algum modo, estabelecer relações entre sua vida e sua obra. Os cerca de vinte livros publicados pelo autor e traduzidos para idiomas como o francês, o alemão e o inglês trazem a marca dessa trajetória político-ideológica na qual esteve intimamente envolvido desde muito jovem. Entretanto, as relações entre a literatura e a história nacional que podem ser encontradas nas obras de Mia Couto, bem como nas de seus pares, não permitem concluir que os autores africanos constroem, ou desejam construir, uma barreira que os separe das influências externas, para proteger a assim chamada "tradição" do continente. Em texto publicado em 2005, o próprio autor questiona a verdadeira origem das tradições africanas que muitos intelectuais consideram legítimas e as quais tentam salvaguardar a todo custo:

Os mais ferozes defensores do nacionalismo cultural africano estão desenhando casas ao avesso mas ainda no quadro da arquitetura do Outro, daquilo que chamamos o Ocidente. De pouco vale uma atitude fetichista virada para os costumes, o folclore e as tradições. A dominação colonial inventou grande parte do passado e da tradição africana. Alguns intelectuais africanos, ironicamente, para negarem a Europa acabaram abraçando conceitos coloniais europeus (COUTO, 2005, p. 62).

Para o escritor, há uma evidente diferença entre a realidade vivida pelos africanos e a construção de arquétipos e estereótipos com os quais o imaginário ocidental alimentou parte de sua arte. Muitos dos mitos e lendas que compõem a tão cantada riqueza cultural da África talvez existam mais no discurso oficial do invasor do que dentro do território moçambicano ou em meio a sua gente. Ainda assim, os romances de Mia Couto são repletos de ritos a que as personagens se submetem sem questionar, como se obedecessem a um chamado vindo de algo ou de alguém sempre pronto a punir aqueles que cedem à tentação de se desviar dos obscuros preceitos ditados por essa África ancestral. Porém, tal contradição pode ser expli- 
cada pelo lugar que as obras de dois escritores brasileiros ocupam em seu trabalho e em sua vida: Jorge Amado e Guimarães Rosa. Mia Couto escreve sobre a enorme influência dos romances do autor baiano para artistas que, como ele, debatiam-se em meio à contradição que consistia em tentar denunciar a violência do invasor usando a própria língua trazida por ele:

$\mathrm{Na}$ altura, nós carecíamos de um português sem Portugal, de um idioma que, sendo do Outro, nos ajudasse a encontrar uma identidade própria. Até se dar o encontro com o português brasileiro, nós falávamos uma língua que não nos falava. E ter uma língua assim, por metade, é outro modo de viver calado. Jorge Amado e os brasileiros nos devolviam a fala, num outro português, mais açucarado, mais a jeito de ser nosso (COUTO, 2011, p. 66).

O português falado no Brasil, amaneirado, adaptado às curvas de uma terra em tudo diferente da de Portugal, tendo sido recriado nos textos de Jorge Amado, parecia, finalmente, libertar os escritores moçambicanos do mal-estar que a mistura da história do seu país com o idioma luso neles provocava. Entretanto, a maior contribuição para seu próprio pensamento autoral Mia Couto identificaria na escrita de Guimarães Rosa, que inventava não somente uma nova forma de utilizar a língua - ainda mais distante de Portugal que a de Jorge Amado -, mas também uma nova terra, repleta de novos mitos. Para Mia Couto, a sacralização de tradições é a maneira que muitos africanos encontram de rejeitar a vida real, aferrando-se a uma ideia de país e de continente que apenas podem ser considerados vivos enquanto se apoiam em um tempo morto. E era justamente o inverso dessa moeda que o autor moçambicano descobria na literatura de Guimarães Rosa: "O que a escrita de Rosa sugeria era uma espécie de inversão deste processo de recusa. Tratava-se não de erguer uma nação mistificada, mas da construção do mito como nação" (COUTO, 2011, p. 112).

O mito erguido por Guimarães Rosa, na visão de Mia Couto, é evidenciado pelo sertão fantástico que o escritor brasileiro criou para dar abrigo a suas personagens. Segundo o autor moçambicano, a palavra "sertão" foi levada para as terras da África pelo colonizador português, que com ela tentou batizar a savana. Porém, esse termo não sobreviveu em solo africano, "não criou raízes", simplesmente porque não penetrou no coração do povo, e o sertão - palavra e lugar -, tanto para o escritor brasileiro quanto para o moçambicano, mora dentro das pessoas. Em um país que, segundo Mia Couto, vive ainda o momento de criar para si um espaço próprio - descolado do colonizador e das ilusões de legitimidade acerca da tradição, um espaço no qual a população possa encenar a sua própria ficção, "enquanto criaturas portadoras de História e fazedoras de futuro" -, o sertão mítico de Guimarães Rosa ainda está por ser encontrado (COUTO, 2011, p. 110). E é isso o que o autor moçambicano, de certa maneira, procura com sua literatura, sobretudo através do modo como faz da praia em Terra sonâmbula (2007), da floresta em O último voo do flamingo (2005) e 
da savana em Antes de nascer o mundo (2009), só para citar alguns exemplos, seus mais recorrentes espaços ficcionais. Na literatura do biólogo Mia Couto, a natureza africana é o "mito como nação".

Em 2011, Mia Couto publicou E se Obama fosse africano?, coletânea de intervenções feitas por ele em congressos e seminários dos quais vem tomando parte desde que sua escrita lhe permitiu alcançar lugares localizados para além do país e do continente em que nasceu. No mesmo texto em que procura dimensionar a influência de Guimarães Rosa no trabalho e no pensamento dos escritores moçambicanos, o autor resume, em menos de um parágrafo, tudo o que precisa ser dito sobre sua história, sua escrita e sua pessoa:

Sou moçambicano, filho de portugueses, vivi o sistema colonial, combati pela independência, vivi mudanças radicais do socialismo ao capitalismo, da revolução à guerra civil. Nasci num tempo de charneira, entre um mundo que nascia e outro que morria. Entre uma pátria que nunca houve e outra que ainda está nascendo. Essa condição de um ser de fronteira marcou-me para sempre. As duas partes de mim exigiam um médium, um tradutor. A poesia veio em meu socorro para criar essa ponte entre dois mundos aparentemente distantes (COUTO, 2011, p. 116).

Mia Couto vê-se como um homem dividido, no sentido de que suas origens remontam à realidade de países tão radicalmente diferentes quanto Moçambique e Portugal, e de que o despertar de sua consciência ideológica se deu em um período fronteiriço, de enormes modificações políticas e sociais ocorridas em ambos os continentes. A poesia presente em sua escrita é o elemento que ele julga ser capaz de conectá-lo aos dois mundos de que faz parte, mas aos quais não consegue sentir-se plenamente pertencente senão por meio da linguagem literária, e de colocar em relação esses dois universos. No mesmo texto em que se define como um ser de fronteira, Mia Couto afirma que os antepassados sepultados na terra da África se convertem em deuses, em divindades a que os vivos recorrem para compreender e traduzir a realidade, e com as quais eles dialogam em busca de conciliação e paz. Todavia, ele mesmo, devido a sua condição de filho e neto de portugueses, não consegue alcançar essas divindades de modo pleno: "Eu não podia partilhar por inteiro daquela conversa entre deuses e homens. Porque eu estava já carregado de Europa, minha alma já bebera de um pensamento. E os meus mortos residiam num outro chão, longínquo e inacessível" (COUTO, 2011, p. 117).

Em Um rio chamado tempo, uma casa chamada terra, romance publicado em 2002, Mia Couto mistura vivos e mortos numa trama que gira em torno de um funeral. Esse funeral solicita a celebração de rituais sem os quais o falecido avô do narrador protagonista seria, para sempre, um morto incompleto. Nessa obra, nascimento e morte são como as duas faces de uma mesma moeda, ou os dois estágios de uma mesma existência: 
"A morte é como o umbigo: o quanto nela existe é sua cicatriz, a lembrança de uma anterior existência" (COUTO, 2003, p. 15). Em alguns casos, mesmo os nomes utilizados para designar plantio e sepultamento ou para batizar a casa que abriga os vivos e a terra que recebe os mortos se confundem, aproximando os dois mundos:

A palavra que usara? Plantar. Diz-se assim na língua de Luar-do-Chão. Não é enterrar. É plantar o defunto. Porque o morto é coisa viva. E o túmulo do chefe de família como é chamado? De yindlhu, casa. Exactamente a mesma palavra que designa a moradia dos vivos (COUTO, 2003, p. 86).

Luar-de-Chão, o lugar onde Mia Couto situa sua história, apesar de ser uma ilha habitada, é um lugar sufocante e árido, cercado de medo por todos os lados. Mariano, o jovem que volta à vila para participar dos rituais de sepultamento do avô de quem herdou o nome, é avisado sobre isso por meio de uma das misteriosas cartas que passa a receber do insepulto parente: "A ilha de Luar-de-Chão é uma prisão. A pior prisão, sem muros, sem grades. Só o medo do que há lá fora nos prende ao chão" (COUTO, 2003, p. 65). A morte e o encarceramento - físico e metafísico - são temas recorrentes no universo ficcional de Mia Couto; estão presentes na narrativa citada assim como estão em Vinte e zinco, romance encomendado pela editora que publica suas obras em Portugal e lançado naquele país em 1999. No relato, o escritor mostra a obstinação com que suas personagens portugueses e moçambicanos - agarravam-se a uma ideia de existência que não mais podia ser mantida ao final do colonialismo, a ponto de parecerem prestes a naufragar junto com ele, ao mesmo tempo em que aponta o modo como as lembranças de crueldade e tirania deixadas por um homem já morto constituíam-se no único sustentáculo de uma família inteira.

A essa temática Mia Couto retorna em Venenos de Deus, remédios do Diabo, obra de 2008 publicada, simultaneamente, em Moçambique, Portugal e Brasil ${ }^{3}$, na qual um velho doente - habitando a fronteira entre a vida, da qual, então, pode apenas se recordar, e a morte, que o espreita a cada passo - mantém as pessoas que o rodeiam atadas às palavras que profere e à sua figura que se desvanece pouco a pouco. Entretanto, a presença da morte nos romances do autor, mais do que representar uma espécie de aquiescência sua em relação ao pensamento que o Ocidente formula sobre a África, ou a um sentido de tragédia que, em parte, emana do continente e que, não obstante, é sistematicamente reforçado pelo olhar de fora, configura-se como um sutil movimento de procura, por parte das personagens e, de certo modo, também por parte do escritor, desse espírito vivo que parece refluir de uma terra repleta de mortos.

Foi também procurando identificar um lugar para si no país em que nasceu que Mia Couto, a certa altura de sua vida, envolveu-se com a militância política em Moçambique. Em uma entrevista recente concedida a um programa de televisão brasileiro ${ }^{4}$, o autor explica da seguinte maneira parte da importância e das boas lembranças que guarda do tempo em que colaborou com a FRELIMO: 
Eu venho de uma família muito pequena. São dois portugueses que emigram para a África [...]. Eu tinha uma inveja enorme daqueles outros meninos que tinham avós e tios e primos e etc. Eu não tinha nada disso e, portanto, eu acho que tenho essa necessidade de chegar a uma família maior, e essa família era um país inteiro durante um certo momento ${ }^{5}$ (COUTO, 2012).

Em certa medida, nessa fala do autor, ecoa uma característica que ele encontra em muitas das línguas africanas e que se converteu, nas cidades e vilarejos do continente, em um costume social, o de se considerar verdadeiramente pobre o indivíduo que não possui laços familiares. Tal costume - ao qual já havia aludido tanto em textos publicados em E se Obama fosse africano? quanto na primeira coletânea de ensaios, crônicas e intervenções que lançou em 2005 e que batizou com o emblemático nome de Pensatempos -, ao ser ficcionalizado, tornou-se parte daquilo que o narrador de Um rio chamado tempo, uma casa chamada terra revela sobre o modo de ser e de expressar-se dos habitantes do lugar onde nasceu: "Em Luar-de-Chão não há palavra para dizer 'pobre’. Diz-se 'órfão'. Essa é a verdadeira miséria: não ter parente" (COUTO, 2003, p. 136). A inveja que o autor diz ter sentido, quando criança, dos meninos que tinham familiares ao alcance de suas mãos e à disposição de seus pensamentos é a constatação, por parte de Mia Couto, de que na África lhe faltam, igualmente, mortos e vivos. Por outro lado, recorrendo à linguagem literária como ferramenta conciliatória e unificadora, ele consegue erguer pontes entre a ascendência europeia de que participa e a herança africana à qual, talvez, aspire.

Essa religação entre Portugal e Moçambique que Mia Couto promove com sua literatura é, também, uma religação linguística. Em um dos textos publicados em Pensatempos, o autor relembra as circunstâncias que o levaram a escrever Vinte e zinco e o fato de que, entre seus receios, estava o da provável impossibilidade de se traduzir para outros idiomas, de maneira fiel, o efeito que tentara criar com tal título:

Infelizmente, é difícil que traduções para outras línguas guardem a reinvenção lexical operada em português. O jogo de palavras em português marca, porém, o distanciamento de dois universos que olham de forma diversa uma mesma efeméride. Os que viviam nos bairros de zinco (os subúrbios pobres) fizeram festa total no 25 de Junho de 1975, data da independência nacional. Sorriram no 25 de Abril de 1974 mas cantaram e dançaram no 25 de Junho de 1975 (COUTO, 2005, p. 58).

As datas mencionadas pelo autor fazem referência à declaração de independência de Moçambique em relação a Portugal e à Revolução dos Cravos, que pôs fim ao regime fascista do Estado Novo, implantado no país europeu pelo general Salazar nos anos 1930 e vigente por mais de quatro décadas. A queda do Estado Novo abriu caminho para a libertação das colônias portuguesas na África. Porém, o mais importante aqui 
não é a história que antecede e, em algum nível, inspira a criação artística, e sim o modo encontrado pelo autor de transformá-la na matéria de sua arte, por meio da união que promove entre a língua de seus antepassados e as diversas formas através das quais o povo moçambicano se expressa. $\mathrm{O}$ zinco dos casebres nos quais os pobres de seu país se abrigam, misturado a uma data que remonta a dois momentos de convergência entre a história de Moçambique e de Portugal, de certa maneira, une duas realidades como a agulha e a linha de costura são capazes de unir dois pedaços de tecido, não importando o quão dessemelhantes eles possam parecer em extensão, textura e cor.

Uma das evidências dessa costura linguístico-contextual promovida por Mia Couto pode ser encontrada já no título do livro de contos Estórias abensonhadas, publicado em 1994, no qual as bênçãos e os sonhos conjugam-se com o intuito de antecipar o universo que será encontrado entre suas páginas. No entanto, a união de realidades diferentes e consciências diversas que Mia Couto procura promover por intermédio de sua escrita vai muito além do deslocamento de palavras ou da extensa criação de neologismos que opera ao recorrer à junção de vocábulos e à subversão de categorias gramaticais. De certa forma, Mia Couto sintetiza, nos narradores e personagens de seus romances, nas vozes e personalidades que não cabem em definições unidimensionais, um pouco das dicotomias que lhe marcaram a vida e estiveram, desde sempre, associadas a sua pessoa pública.

\section{REFERÊNCIAS BIBLIOGRÁFICAS}

BHABHA, Homi. O local da cultura. Trad. Myriam Ávila, Eliana Lourenço de Lima Reis e Gláucia Renate Gonçalves. Belo Horizonte: Editora UFMG, 2014.

COUTO, Mia. Vinte e zinco. Lisboa: Editorial Caminho, 1999.

- Um rio chamado tempo, uma casa chamada terra. São Paulo: Companhia das Letras, 2003.

. O último voo do flamingo. São Paulo: Companhia das Letras, 2005.

. Pensatempos: textos de opinião. Lisboa: Editorial Caminho, 2005.

. Terra sonâmbula. São Paulo: Companhia das Letras, 2007.

- Venenos de Deus, remédios do Diabo. São Paulo: Companhia das Letras, 2008.

. Antes de nascer o mundo. São Paulo: Companhia das Letras, 2009. 
2011.

. Estórias abensonhadas. São Paulo: Companhia das Letras,

2012.

CURY, Maria Z. Ferreira; FONSECA, Maria N. Soares. Mia Couto: espaços ficcionais. Belo Horizonte: Autêntica Editora, 2008.

HALL, Stuart. A identidade cultural na pós-modernidade. Trad. Tomaz Tadeu da Silva e Guacira Lopes Louro. 11ª ed. Rio de Janeiro: DP\&A, 2006.

HUTCHEON, Linda. Poética do pós-modernismo: história, teoria, ficção. Trad. Ricardo Cruz. Rio de Janeiro: Imago, 1991.

RODA VIVA. Divulgação: depoimento. [Nov. 2012]. Entrevistador: Mário Sérgio Conti. São Paulo: TV Cultura, 2012. Disponível em: $<$ https:// www.youtube.com/watch?v=6v3buePuzbU>. Acesso em: 25 jun. 2015.

Recebido para publicação em 18/09/2015

Aprovado em 03/01/2016

\section{NOTAS}

* Raquel Aparecida Cesar da Silva é doutoranda em Letras pela Universidade de Passo Fundo (UPF); bolsista CAPES. Possui experiência na área de literaturas em língua portuguesa, com ênfase nas africanas. Atua, principalmente, em pesquisas relacionadas aos seguintes temas: contexto histórico, identidade cultural, diálogo interartes e paisagem e alteridade em literaturas lusófonas contemporâneas. Contato: raquelcesar77@gmail.com Márcia Helena Saldanha Barbosa é professora de Literaturas de Língua Portuguesa na Universidade de Passo Fundo (UPF) e doutora em Teoria da Literatura (PUC-RS), com pós-doutorado na Universidade Federal Fluminense (UFF). É colaboradora do Grupo de Pesquisa "Estudos de Paisagem nas Literaturas de Língua Portuguesa" e autora de Sophia de Mello Breyner: leitora de Camões, Cesário Verde e Fernando Pessoa. Contato: mhsbarbosa@gmail.com

2 Em entrevista citada no estudo Mia Couto: espaços ficcionais, o autor relata como a poesia parecia onipresente na casa onde vivia com os pais e os irmãos: "Eu estava cercado: em minha própria casa não só estava o livro mas o poema em carne e alma. E estava, sobretudo, minha mãe que era, a meus olhos, a própria poesia." (CURY; FONSECA, 2008, p. 19).

3 O lançamento simultâneo de Venenos de Deus, remédios do Diabo em três países de diferentes continentes constituiu-se em um acontecimento até então inédito na carreira de Mia Couto.

4 A entrevista, um dos compromissos assumidos pelo autor no que refere à divulgação do romance A confissão da leoa no Brasil, foi concedida ao programa Roda Viva, da TV Cultura, e transmitida, ao vivo, no dia cinco de novembro de 2012.

$5 \mathrm{O}$ fragmento, transcrito por nós, corresponde aos $32 \mathrm{~min} 54 \mathrm{~s}$ de uma entrevista que, em sua totalidade, alcança $1 \mathrm{~h} 23 \mathrm{~min}$ de duração. 